\title{
Police Officers' Use of Discretion in Forced Repatriations of Unaccompanied, Asylum-seeking Refugee Children-Balancing Efficiency and Dignity
}

\author{
Jonas Hansson ${ }^{1,2, *}$ Mehdi Ghazinour ${ }^{2,3}$, Malin E Wimelius ${ }^{4}$ \\ ${ }^{1}$ Department of Public Health and Clinical Medicine, Epidemiology and Global Health, Umeå University, Sweden \\ ${ }^{2}$ Basic Training Programme for Police Officers, Umeå University, Sweden \\ ${ }^{3}$ Department of Social Work, Umeå University, Sweden \\ ${ }^{4}$ Department of Political Science, Umeå University, Sweden \\ *Corresponding Author: jonas.hansson@umu.se
}

\begin{abstract}
Many countries in the European Union (EU) - among them Sweden - are engaged in accelerated removals of refugees, including unaccompanied, asylum-seeking refugee children. Based on the Universal Declaration of Human Rights and the United Nations Convention on the Rights of the Child (CRC), international directives and national policies prescribe that the dignity of refugees must be respected when they are forcibly repatriated to their countries of origin. Simultaneously however, the government demands that police services improve their efficiency by continuously increasing the number of forced repatriations, something that prompts a question on the relationship between efficiency and dignity. To what extent is there a conflict between these two goals? Against this backdrop, the aim of this paper is to explore and analyse how Swedish police officers perceive their participation in forced repatriations of unaccompanied, asylum-seeking refugee children. Interviews with police officers were conducted and analysed drawing on Lipsky's street-level bureaucracy perspective. The findings show that police officers use discretion to create individual perceptions of what constitutes an efficient and dignified repatriation. One main conclusion is that they perceive no conflict between efficiency and dignity. The police officers' own interpretations of what dignity is make it cognitively possible for them to combine efficiency and dignity.
\end{abstract}

Keywords Discretion, Police, Street-level Bureaucracy, Unaccompanied Asylum-seeking Refugee Children

\section{Introduction}

In the past ten years, the number of unaccompanied asylum-seeking refugee children has increased dramatically in the European Union (EU). In 2014, 7,049 unaccompanied refugee children applied for asylum in Sweden. This is a significant increase compared to 388 in 2004 and 2,250 in 2009 (Swedish Migration Board, 2015). The United Nations High Commissioner for Refugees (UNHCR) as well as the EU, have repeatedly stressed that unaccompanied children should be considered to be especially vulnerable as they have experienced a number of losses, separations and other traumatic events (2008/115/EC; Ní Raghallaigh, 2013; Sourander, 1998; UN Committee on the Rights of the Child, 2005).

Research on unaccompanied, asylum-seeking refugee children is only beginning to emerge due to empirical as well as theoretical neglect (Chavez \& Menjívar, 2010). To date, the literature has predominantly focused on the children's health and resilience in the recipient country (Bean, Derluyn, Eurelings-Bontekoe, Broekaert, \& Spinhoven, 2007; Derluyn \& Broekaert, 2007; Ní Raghallaigh \& Gilligan, 2010; Ní Raghallaigh, 2011). There are also a number of studies on children's rights (Baum, Revenson, \& Singer, 2012; Fekete, 2007; Fritsch, Johnson, \& Juska, 2010; Mann, 2010; Shamseldin, 2012) and a few on professionals working with such children (Ní Raghallaigh, 2013; Westwood, 2012). However, research on repatriation is very rare (Kohli, 2011). Fekete (2011) is one of only a few scholars who have taken an interest in forced repatriation. Her studies show that although unaccompanied asylum-seeking refugee children should be regarded as especially vulnerable, many EU countries-including Sweden - are engaged in policies of accelerated removals of refugees, therein targeting these same children. Removals often involve the use of force, something that not only threatens the refugees' human rights, but also their lives (Fekete, 2011; cf. Zorn, 2009). According to Fekete, teenagers are often among the most resilient in 
asylum and migrant communities, but her research shows several records of suicides among unaccompanied, asylum-seeking refugee children in reception facilities and detention centres. Other children simply disappear. A Dutch study (Kromhout, 2011) showed that unaccompanied, asylum-seeking refugee children vanished from reception centres instead of returning to their country of origin after having their application for asylum rejected. The study also revealed a significant lack of trust between the children and the professionals working with them.

Against this backdrop we find it interesting that the Swedish government has set the ambitious goal of significantly increasing the efficiency of forced repatriations (Swedish Government, 2014a, 2014b). However, the government as well as the National Police Board, by using a process-oriented method called Lean, have emphasized that dignity and respect for fundamental human rights must not be sacrificed in the pursuit of increased efficiency (RPSFS 2005:3; SOU 2009:60). This is enshrined within EU guidelines, the Universal Declaration of Human Rights (UDHR) and in the CRC (2008/115/EC; Council of Europe, 2005; UN General Assembly, 1948, 1989). According to Article 1 of the UDHR, 'All human beings are born free and equal in dignity and rights' (UN General Assembly, 1948, p. 2) and according to Article 3.1 in the CRC, ' $[\mathrm{I}] \mathrm{n}$ all actions concerning children, whether undertaken by public or private social welfare institutions, courts of law, administrative authorities or legislative bodies, the best interests of the child shall be a primary consideration' (UN General Assembly, 1989, p. 3).

In Sweden, the police authorities are responsible for forced removals of refugees, but there is very little research on how police officers perceive, approach and act in forced repatriations of refugees in general and unaccompanied, asylum-seeking refugee children in particular. The aim of this paper is therefore to explore and analyze how Swedish police officers perceive their participation in such repatriations. Such an exploration is especially interesting when set against what seems to be a potentially challenging task; to increase the number of repatriations without compromising the human rights of unaccompanied, asylum-seeking refugee children. We have interviewed 14 police officers in Sweden in order to investigate and analyze what, according to them, an efficient and dignified repatriation is.

In a study of professionals' perceptions and practices in relation to refugee children's human rights, Ottosson, Eastmond, and Schierenbeck (2013) analyzed children's case workers at the Swedish Migration Board taking their points of departure from Lipsky's (2010) theory on street-level bureaucrats. In analytical terms, we are in agreement with them that the perceptions and practices of street-level bureaucrats are the keys to understanding how potentially conflicting political goals are interpreted in relation to a vulnerable group. In our case this is to establish how police officers interpret increased efficiency and dignity in relation to unaccompanied, asylum-seeking refugee children who are about to be deported. This is why we commence by using Lipsky's (2010) classical notion of police officers as street-level bureaucrats with wide discretionary powers. Such an approach will help us analyze how police officers relate to, interpret and implement these goals in practice and how they exercise their relative autonomy in this case. By exploring these issues we intend to contribute to a small but growing international literature on how police officers perceive forced repatriations of unaccompanied, asylum-seeking refugee children in a policy context of accelerated removals.

The paper begins by providing the background in which the grounds for permanent residence permits in Sweden are discussed. We also describe the Swedish police services, focusing on their role in enforced repatriations. A section that outlines the core concepts of Lipsky's theory follows this background. The design and method of the study is then presented, followed by our findings, together with a discussion and our conclusions.

\section{Background}

When examining a child's case for asylum, it is legally required to consider the child's age, health and other circumstances, for instance the situation in the country of origin (SFS 2005:716). In Sweden, an unaccompanied refugee child can be granted a permanent residence permit on three grounds. First, if the child is considered a refugee in accordance with the United Nations Refugee Convention; second, if the child is in need of subsidiary protection in accordance with joint EU regulations; and third, if the child is in need of protection in accordance with the Swedish National Aliens Act. From July 2014, an unaccompanied, asylum-seeking refugee child can also receive protection in Sweden under specific distressing circumstances. The Aliens Act previously referred to 'particularly' distressing circumstances. The change to the legally wider term 'specific' has been motivated by explicit references to the needs of unaccompanied, asylum-seeking refugee children and is expected to make it easier for these children to gain permanent residence permits in Sweden.

Intended to promote justice and security, the work of the Swedish police is aimed at: maintaining public order and security; ensuring public protection; providing assistance; preventing crime; solving crime; monitoring public order and safety; conducting reconnaissance; and carrying out criminal investigations. Furthermore, they shall provide public protection, information and any other appropriate assistance that they can give. Finally, they shall cooperate with prosecution authorities, social services and any other agencies and organizations whose activities are affected by policing (SFS 1984:387).

A specific task for police officers is to collaborate with the Swedish Migration Board on unaccompanied, asylum-seeking refugee children. If an unaccompanied, asylum-seeking refugee child is denied a permanent 
residence permit, he or she can-assisted by a public counsel - appeal to the Migration Court as a first resort, and to the Migration Court of Appeal as a second. This takes time, anything from three up to eight months. Unaccompanied, asylum-seeking refugee children will have to leave the country after receiving a final negative decision. If a child refuses to cooperate and does not want to return voluntarily, the Swedish Migration Board may, according to Chapter 12, paragraph 14 of the Aliens Act (SFS 2005:716), delegate the enforcement of the case to the police authority. The police authority is then consequently responsible for the enforcement of these forced repatriations.

\section{Enforced Repatriations of Unaccompanied, Asylum-Seeking Refugee Children}

The assignment to enforce repatriations of migrants is extremely complex. Generally, the police begin by establishing contact with the individual to be deported. In accordance with the Return Directive and EU Guidelines the purpose of the contact is to create a situation in which the individual agrees to voluntarily return to their country of origin or at least cooperate to make the return possible (2008/115/EC; Council of Europe, 2005). Unaccompanied, asylum-seeking refugee children often disappear from the care homes at which they are accommodated during the asylum process if the police contact them before the repatriation. If the child does disappear, the police then denote them as a missing person. In order to avoid such disappearances, the police will usually contact the director of the care home and inform him or her of when they will show up and initiate the repatriation process. Under these circumstances the police usually plan to come to the care home early in the morning, collect the child and begin their journey back to their country of origin.

\section{Analytical Framework}

This study uses Lipsky's street-level bureaucracy framework. According to Lipsky, street-level bureaucrats are 'public service workers who directly interact with citizens in the course of their jobs, and who have substantial discretion in their execution of their work' (Lipsky, 2010, p. 3). He argued that discretion involved a balance between implementing societal rules and legislation and being responsive and flexible to the citizen's needs. To exercise discretion means that the police establish independent priorities and interpretations, disregard rules, invent praxis and obstruct. Moreover, Lipsky (2010) argued that frontline public officials were the ones who truly made policy, which created inconsistencies and inequalities in access to and administration of services. These officials become shock absorbers between the policymakers and the public. Wide discretionary powers allow them to treat people as the unique individuals they are in a system based on equality. Police officers, teachers and social workers should therefore be seen as part of the 'policy-making community' and as exercisers of political power. For example, a police officer may decide whom to give a ticket to for a traffic violation or arrest for an offence.

Lipsky (2010) also investigated why organisations sometimes act contrary to their own rules and goals. He suggested that we need to know how the rules are practised by workers in the organization, what space workers have in acting on their own preferences, and what other demands they experience. The reality for street-level bureaucrats is often that of a shortage of time and limited resources, which lead to simplifications and shortcuts. Lipsky also noted that demand for services tends to increase to meet the supply; that goal expectations tend to be vague, ambiguous or conflicting; that goal achievement is difficult if not impossible to measure; and that most clients are involuntary. Furthermore, he argued that in police work, officers constantly have to weigh different interests against one another. Although laws and regulations steer them, they must take into account the people they meet in their daily work.

Police officers working with forced repatriations face two overarching political demands: increase the number of forced repatriations (Swedish Government, 2014b) but do so without compromising the children's human rights (2008/115/EC). A key word in this context is dignity, which is often interpreted as giving the child an opportunity to prepare for repatriation. This preparation can involve the use of contacts in the host country and the country of origin, and also providing children with the opportunity to retrieve personal belongings. In addition, the repatriation may be interrupted if the children's safety and dignity is endangered (Council of Europe, 2005).

When it comes to forced repatriations in Sweden, the character of political steering makes these interpretations of efficiency and human rights the responsibility of the police officers. They are expected to use their autonomy and discretion in this respect. In theoretical terms police officers can therefore be regarded as street-level bureaucrats. Drawing on Lipsky we raise analytical questions in order to learn how the interviewed police officers balance the goals of increased efficiency and respect for unaccompanied, asylum-seeking refugee children's dignity and human rights. How do they use their discretion? How do they interpret and implement these goals and to what extent do they make independent priorities and invent praxis?

\section{Method}

\section{Participants and Procedure}

The Swedish Police Service was, until 2014, composed of 21 county police authorities. On 1 January 2015, the Swedish Police Service was converted into one National Police Authority. The 21 authorities had geographical areas of responsibility corresponding to county boundaries. The number of employees within each police authority varied, 
while $30 \%$ of the 19,911 police officers were women and the average age among all officers was 43.8 years (National Police Board, 2014). Most of the police authorities had a border police unit. Our data setting included five police authorities, four of which employed between 300 and 500 police officers with five to ten deployed at the border police unit or a similar unit. The fifth authority employed around 3,000 police officers with 50 officers deployed at the border police unit or similar. In addition, the border police units had civil officials. After approval by the Regional Ethics Committee at Umeå University (2014/69-31Ö), we interviewed a total of 14 police officers working in these five authorities in Sweden. They were eleven men and three women, aged between 35 and 65 with an average working experience of 18 years. The sample of respondents was identified through contact with the head of the border police unit in each police authority. First, the officers were informed about the project by email. Enclosed was a consent letter explaining the ethical principles guiding the research project. An appointment then was planned. Before the interview, the respondents were reminded of the purpose of the study and fully informed of their right not to participate and withdraw at any time. Full confidentiality and anonymity of respondents was maintained (Research Council, 2002). Confidentiality was guaranteed by omitting the respondents' names and identities in the recorded and transcribed interviews. Five face-to-face and nine telephone interviews were conducted, recorded and verbatim transcribed. Due to extensive geographical distances we decided to use telephone interviews - a method that functioned as well as face-to-face interviews. Following Kvale and Brinkmann's (2009) recommendation which is to interview as many respondents as needed in order to thoroughly answer an interview question, interviews were conducted until the answers did not add anything new to the previous ones. Using a thematic interview guide, semi-structured interviews lasted between 60 and 90 minutes.

\section{Analysis}

The thematic interview guide was structured building on the analytical framework of the study. The study is consequently a theoretical thematic analysis driven by theoretical and analytic interests (Braun \& Clarke, 2006). Themes in the interview guide included questions about the United Nations Convention on the Rights of the Child (CRC), national policies and potential conflicts between efficiency and dignity. These themes and the analytical framework helped interpret the respondents' experiences and perceptions of the repatriation process as we focused on their interpretations of efficiency and dignity (Braun \& Clarke, 2006). The analysis was also inspired by Graneheim and Lundman's (2004) approach to content analysis. The latter implies that first we read the interview transcripts several times to obtain a sense of all of the content. We then divided the text into condensed meaning units on order to get an in-depth sense of the interviews. The condensed meaning units were discussed by the authors during this analysis and then theorised about the significance of the patterns (Braun and Clarke, 2006). In the findings section, we use quotations from the interviews to illustrate general patterns but also to highlight differences with regard to perceptions, experiences and interpretations.

\section{Findings}

The following section describes the respondents' perceptions of working with forced repatriations of unaccompanied, asylum-seeking refugee children; these are analyzed drawing on Lipsky's ideas.

The first question we were concerned with revolved around how police officers perceive the demand to increase the number of repatriations on the one hand, and respect children's dignity and human rights on the other. The findings show that police officers do not perceive an obvious tension between efficiency and dignity. Most seem to think of the two as mutually reinforcing. However, the findings also show that the police officers made up their own personal definitions of and approaches to dignity. In general they associated dignity with what they interpreted as being the right and good thing to do from their own perspectives and frames of references.

The second research question explored in more detail what police officers think constitutes an efficient and dignified repatriation. The findings in this respect show that police officers use their wide discretionary powers to make independent priorities but that-again-good and kind treatment of the children was emphasized as a key factor. Interestingly enough, we found that in all five police authorities significant changes had been made in order to increase and enable a measurement of efficiency. Lean-based process-oriented working methods had been introduced, something that we will return to and discuss later.

\section{Interpretations of Efficiency and Dignity}

The interviewed police officers all argued that they are unable to do anything about the enforcement order once they receive an assignment to deport a child. The decision has been made by the Swedish Migration Board or by a court of law. However, the officers think they can 'do their best for the child' and implement the decision to deport the child 'in the best way'.

A majority of the respondents argued that efficiency is important, but also emphasized the importance of not sacrificing fundamental values, as expressed in the CRC. One of them stated that 'efficiency does not mean one should stop thinking'. Respondents also generally stressed that not sacrificing fundamental values requires professional knowledge and that at the end of the day 'the child's rights shall be in the first place'. This is similar to what Ottosson et al. (2013) found in their study of children's case workers; these workers also emphasized the importance of the child's perspective, but related to such a perspective on their own 
terms. In the same fashion, police officers think of the 'child's best interest' from their own point of view. One of the respondents interpreted 'the child's best interest' related to the experience of 'having my own children'. Another respondent stated that 'the child's best interest must come first because the CRC says so' but also interpreted the child's best interest with explicit reference to the Return Directive 'meaning to be reunited with their family'.

We argue that these interpretations make it cognitively possible for police officers to combine efficiency and dignity. Lipsky (2010) showed how lack of external goals and expectations lead street-level bureaucrats to use discretion. In our case, police officers invent their own working order because they are not informed or instructed beforehand on how to combine increased efficiency and dignity. We assume that police officers are aware of the goals, namely follow the law when the Swedish Migration Board requests assistance; the tension area is consequently rather the issue of 'how'. We assume that in order to balance this tension between their own rules and the law, the officers utilize discretion. With discretion, they construct a reality that makes it possible for them to fulfill their tasks. Similarly, Armenta (2012) found that immigration officers pursing criminal aliens were guided more by their own thoughts of right and wrong than the law. The immigration officers' discretion made them more active in their fight towards criminal aliens in the US. This task-oriented approach may also be comparable to the concepts of agency and pragmatic improvisation that Maynard-Moody and Musheno (2012) suggest as an alternative to the implementation-control-discretion description.

In our study the findings show that the police officers used discretion to focus on good and kind treatment of the children to make the repatriation dignified. According to the police officers, a 'good and kind treatment' is to treat the child with 'respect', 'warmth and dignity', and the police intervention needs to be 'discreet and nice', 'peaceful', 'smooth and efficient' and 'considerate towards the children'. Furthermore, for a 'good and kind treatment' the police officers need to be 'professional', 'flexible' and 'prestigeless' and behave 'clearly', 'correctly and nicely', 'calmly and harmoniously'. These descriptions can be related to some of the reasons Lipsky (2010) identified as to why street-level bureaucrats utilize discretion. He depicted street-level bureaucrats as working in conditions which are too complicated to be reduced to dogmatic systems, and which often require responses of a human dimension to the situation. This is once again a sign of police officers 'making policy' at the street level. This 'good and kind treatment' seems to stand in contrast to Kromhout's (2011) study that showed a lack of trust between children and the professionals working with them. Focusing on a 'good and kind treatment' might also decrease the use of force that according to Fekete (2011) is increasingly common in forced repatriations.

At two of the police authorities, police officers discussed the legal possibilities of taking children into custody before repatriation. According to the Aliens Act, children cannot be taken into custody for more than 72 hours (with a possible extension of another 72 hours). The police officers at these two authorities argued that it would be better, and more dignified, to take children into custody for the time it required to get travel documents in order and make other travel arrangements than to show up early in the morning at a care home trying to catch a child before he or she disappeared. In their experience, children have disappeared as soon as they are told that police officers would show up. They disappeared only to resurface somewhere else in the country and only to be accommodated by the social services in another care home. When later localised by the police and informed of a new date for repatriation, children would disappear yet again. Therefore, in order to make repatriation possible and also-according to the officers-more dignified, they would prefer legislation making it possible to take children into a form of child-adapted custody. In this custody, the police together with social workers could prepare children for repatriation. Respondents also emphasised that opportunities would then be created for these professional adults to influence children to change their minds, start cooperating with Swedish authorities and return to their countries of origin voluntarily.

\section{Making Independent Priorities}

To be able to enforce more cases than the year before, border police units in all the studied police authorities have, as previously mentioned, implemented a new Lean-based work method. The intention of the method is to decrease 'lead times', that is, intervals when a case is just on hold and not being processed although there is work to do. Most of the police officers have noted administrative improvements of case management within the police organisation as a result of this new method. To begin with cases were divided into three groups. The first included cases that could easily be enforced, with no more work to do than reserving a ticket. The second group included enforceable cases where there was work to do, for example, contacting an embassy in order to get travel documents. The third group included cases that often, due to external circumstances, were practically unenforceable. This could be the case when the country of origin declared that it will not receive a person who does not want to return voluntarily. These cases were prioritised by category to increase the number of repatriations, in ascending order of difficulty. However, such a categorisation could change based on external circumstances or a change in client attitude. In this process, police officers used their relative autonomy and their discretionary powers to decide how to prioritize. According to Lipsky (2010), lack of resources can lead to simplifications and shortcuts. Consequently, decreased or increased resources may affect decision-making. At one police authority the unit had experienced a decrease in resources but was still expected to increase enforcements. They chose to take action in cases involving repatriation of criminals, but not in cases involving children. The police 
officers in this authority reported that they had enough immigrant criminals to deport and no time left for unaccompanied, asylum-seeking refugee children; one officer stated, 'It suits me well'. It is well known that political decisions are sometimes implemented in ways not intended by decision-makers. Decisions are too vague, resources are lacking, decisions are misinterpreted, unwanted side effects occur, or the assumptions on cause and effects are simply wrong (Bastien, 2009; Matland, 1995; Meyers, Glaser, \& MacDonald, 1998). This police officer's prioritising of immigrant criminals can therefore also be seen as an unintended side effect. The police are expected to increase the number of enforced repatriations; not make these kinds of priorities. Simultaneously however, lack of resources makes priorities necessary and allocation of resources is also a way to steer the priorities of the police. In addition, the priorities made can be interpreted as a coping strategy. This is similar to what Ottosson et al. (2013) found when they concluded that the children's case workers at the Swedish Migration Board sometimes used their discretion to oppose office norms and resist to what they perceived as morally wrong decisions. Moreover, Lipsky (2010) argued that client differentiation is an important coping strategy when dealing with conflicting demands. Other factors that can make the street-level bureaucrat favour certain people are inherent subjectivity, difficulties assessing the work, inadequacy of feedback and ideology (Lipsky, 2010).

The other police authorities found themselves in quite a different situation with an increase in resources. We found that police officers working at these authorities were more inclined to prioritise cases in groups one and two. However, this was frustrating for some of the police officers. They noted that 'the friendly and cooperative ones are sent home, but we let the troublesome stay'. In this situation, police use discretion as a shock absorber between organizational policy and the individual client (Kanstroom, 2007; Lipsky, 2010). For example, one police officer described how they could wait to enforce repatriation a few weeks, until the child had finished school, if he or she agreed to cooperate. Other officers described situations in which they did more than was legally expected or demanded of them. They would help a child to pick up a cell phone from a workshop before leaving Sweden, check in an extra suitcase for the child at the airport or help the child to get Swedish school grades validated and translated into the child's mother tongue.

\section{Discussion and Conclusions}

This study has explored and analyzed how Swedish police officers perceive their participation in the repatriation of unaccompanied, asylum-seeking refugee children. Such an analysis was especially interesting when set against the backdrop of the seemingly contradicting demands on increasing the number of deportations on the one hand, and respecting children's dignity and human rights on the other. At the policy formulation level, respect for dignity and human rights must not be compromised by increased efficiency. However, at the implementation level, these goals may seem to cause conflict for frontline workers.

Our findings show that although police officers do not perceive the goals in contradictory terms, discretion is a way of managing the tensions that do occur. The police officers' own interpretations of what dignity is make it cognitively possible for them to combine efficiency and dignity. In general, perceptions and interpretations are individual but similar. For instance, most officers interpret the child's best outcome as family reunification. Consequently, they 'believe' that repatriation is best for the child. This may very well be a construction in order to make forced repatriations and the task itself meaningful and intelligible. Police officers also repeatedly refer to good and kind treatment of the children as tools to make repatriation dignified.

However, three observations can be made in this context. First, what we find lacking in the police officers' interpretations of dignity are explicit references to children's human rights; such reflections are very rare and exclusively connected to family reunification. It is telling that the officers who proposed a legal possibility to take children into custody did so without reflecting upon how custody infringes upon the children's human rights and how it would contribute to a criminalisation of asylum-seekers. Second, Lean-based process-oriented working methods have been introduced to improve case management in order to make repatriation work more efficient. This makes it possible to assess and even measure increased efficiency. It is much more challenging to assess or measure dignity and respect for human rights. For that reason it is significantly more difficult for lawmakers to know whether increased efficiency, dignity and respect for human rights are balanced in acceptable ways or if increased efficiency is achieved at the cost of the other two. On the other hand, categorising cases makes priorities possible and it is noteworthy that police units struggling with limited or even diminishing resources use discretion to focus on criminal adults rather than unaccompanied, asylum-seeking refugee children. The latter seems to resonate well with some of the officers' moral convictions and serves to illustrate the space frontline workers have to act on their own preferences and, thereby, invent praxis. Third, summarising the results with regard to the Appropriation directions (Swedish Government, 2014b), we argue that efficiency, dignity and children's human rights should be seen also in the light of unaccompanied, asylum-seeking refugee children's experiences. Their voices need to be heard and their experiences compared to those of police officers. Expressed differently, although increased efficiency is possible to achieve in relation to forced repatriations, unaccompanied, asylum-seeking refugee children's experiences with regard to respect for their human rights and dignity remain unexplored. Although the police do not seem to interpret the goals of increased efficiency and dignity in contradictory terms, it would be highly relevant to examine how this perception affects unaccompanied, asylum-seeking refugee children's legal security and autonomy. 


\section{Acknowledgements}

This work was supported by the European Return Fund under Grant (number R16-209-1-01).

\section{REFERENCES}

2008/115/EC, Directive. OJ L 348 Directive 2008/115/EC of the European Parliament and of the Council of 16 December 2008 on Common Standards and Procedures in Member States for Returning Illegally Staying Third-country Nationals. Strasbourg: European Union

Armenta, A. (2012). From Sheriff's Deputies to Immigration Officers: Screening Immigrant Status in a Tennessee Jail. Law and Policy, 34(2), 191-210. doi: 10.1111/j.1467-9930.2011.00359.x

Bastien, J. (2009). Goal Ambiguity and Informal Discretion in the Implementation of Public Policies: The Case of Spanish Immigration Policy. International Review of Administrative Sciences, 75(4), 665-685. doi: 10.1177/0020852309351472

Baum, A., Revenson, T. A., \& Singer, J. E. (2012). Handbook of Health Psychology (2., [updated] ed.). New York, NY: Psychology Press

Bean, T., Derluyn, I., Eurelings-Bontekoe, E., Broekaert, E., \& Spinhoven, P. (2007). Comparing Psychological Distress, Traumatic Stress Reactions, and Experiences of Unaccompanied Refugee Minors with Experiences of Adolescents Accompanied by Parents. Journal of Nervous and Mental Disease, 195(4), 288-297. doi: 10.1097/01.nmd.0000243751.49499.93

Braun, V., \& Clarke, V. (2006). Using Thematic analysis in Psychology. Qualitative Research in Psychology, 3(2), 77-101. doi: 10.1191/1478088706qp063oa

Chavez, L., \& Menjívar, C. (2010). Children without Borders: A Mapping of the Literature on Unaccompanied Migrant Children to the United States. Migraciones Internacionales, 5(3), 71-111.

Council of Europe, Committee of Ministers. (2005). Twenty Guidelines on Forced Return. Retrieved 15 April 2015 from http://www.refworld.org/docid/42ef32984.html

Derluyn, I. \& Broekaert, E. (2007). Different Perspectives on Emotional and Behavioural Problems in Unaccompanied Refugee Children and Adolescents. Ethnicity and Health, 12(2), 141-162. doi: $10.1080 / 13557850601002296$

Fekete, L. (2007). Detained: Foreign Children in Europe. Race and Class, 49(1), 93-104

Fekete, L. (2011). Accelerated Removals: The Human Cost of EU Deportation Policies. Race and Class, 52(4), 89-97. doi: $10.1177 / 0306396810396605$

Fritsch, C., Johnson, E., \& Juska, A. (2010). The Plight of Zimbabwean Unaccompanied Refugee Minors in South Africa: A Call for Comprehensive Legislative Action. Denver Journal of International Law and Policy, 38, 623-687.

Graneheim, U. H., \& Lundman, B. (2004). Qualitative Content Analysis in Nursing Research: Concepts, Procedures and Measures to Achieve Trustworthiness. Nurse Education Today, 24(2), 105112.
Kanstroom, D. (2007). The Better Part of Valor: The REAL ID Act, Discretion, and the 'Rule' of Immigration Law. New York Law School Law Review, 51(1/2), 165-206.

Kohli, R. K. S. (2011). Working to Ensure Safety, Belonging and Success for Unaccompanied Asylum-seeking Children. Child Abuse Review, 20(5), 311-323.

Kromhout, M. (2011). Return of Separated Children: The Impact of Dutch Policies. International Migration, 49(5), 24-47. doi: 10.1111/j.1468-2435.2009.00587.x

Kvale, S, \& Brinkmann, S. (2009). Den kvalitativa forskningsintervjun (The Qualitative Research Interview). Lund: Studentlitteratur

Lipsky, M. (2010). Street-level Bureaucracy: Dilemmas of the Individual in Public Services (30th anniversary expanded ed.). New York: Russell Sage Foundation

Mann, G. (2010). 'Finding a Life' Among Undocumented Congolese Refugee Children in Tanzania. Children and Society, 24(4), 261-270. doi: 10.1111/j.1099-0860.2010.00310.x

Matland, R. E. (1995). Synthesizing the Implementation Literature: The Ambiguity-Conflict Model of Policy Implementation. Journal of Public Administration Research and Theory, 5(2), 145-174.

Maynard-Moody, S., \& Musheno, M. (2012). Social Equities and Inequities in Practice: Street-Level Workers as Agents and Pragmatists. Public Administration Review, 72(s1), S16-S23. doi: 10.1111/j.1540-6210.2012.02633.x

Meyers, M. K., Glaser, B., \& MacDonald, K. (1998). On the Front Lines of Welfare Delivery: Are Workers Implementing Policy Reforms? Journal of Policy Analysis and Management, 17(1), 1-22. doi:

http://onlinelibrary.wiley.com/journal/10.1002/\%28ISSN\%291520 $-6688 /$ issues

National Police Board. (2014). The Police Service's Annual Report. Retrieved 20 January 2015 from http://polisen.se/Global/www och Intrapolis/Arsredovisningar/01 Polisen

nationellt/Polisen_Arsredovisning 2013.pdf

Ní Raghallaigh, M. (2011). Religion in the Lives of Unaccompanied Minors: An Available and Compelling Coping Resource. British Journal of Social Work, 41(3), 539-556. doi: 10.1093/bjsw/bcq136

Ní Raghallaigh, M. (2013). The Causes of Mistrust amongst Asylum Seekers and Refugees: Insights from Research with Unaccompanied Asylum-Seeking Minors Living in the Republic of Ireland. Journal of Refugee Studies, 27(1), 82-100. doi: $10.1093 / \mathrm{jrs} /$ fet006

Ní Raghallaigh, M., \& Gilligan, R. (2010). Active Survival in the Lives of Unaccompanied Minors: Coping Strategies, Resilience, and the Relevance of Religion. Child and Family Social Work, 15(2), 226-237. doi: 10.1111/j.1365-2206.2009.00663.x

Ottosson, L., Eastmond, M., \& Schierenbeck, I. (2013). Safeguarding a Child Perspective in Asylum Reception: Dilemmas of Children's Case Workers in Sweden. Journal of Refugee Studies, 26(2), 247-264.

Research Council. (2002). Forskningsetiska principer inom humanistisk-samhällsvetenskaplig forskning (Research Ethics Guidelines for Humanities Research and Social Sciences). Stockholm: Vetenskapsrådet 
RPSFS 2005:3. FAP 638-1 National Police Board's Regulations and General Guidelines for the Enforcement of Deportations by Airplane. Stockholm: National Police Board

SFS 1984:387. Police Act. Stockholm: Department of Justice

SFS 2005:716. Aliens Act. Stockholm: Department of Justice

Shamseldin, L. (2012). Implementation of the United Nations Convention on the Rights of the Child 1989 in the Care and Protection of Unaccompanied Asylum Seeking Children: Findings from Empirical Research in England, Ireland and Sweden. International Journal of Children's Rights, 20(1), 90-121. doi: $10.1163 / 157181811$ X570717

SOU 2009:60. Återvändandedirektivet och svensk rätt (Return Directive and Swedish Law). Stockholm: Regeringskansliet

Sourander, A. (1998). Behavior Problems and Traumatic Events of Unaccompanied Refugee Minors. Child Abuse and Neglect, 22(7), 719-727. doi: http://dx.doi.org/10.1016/S0145-2134(98)00053-2

Swedish Government. (2014a). Regleringsbrev för budgetåret 2014 avseende Migrationsverket (Appropriation Directions for the Swedish Migration Board). Retrieved 20 January 2015 from http://www.esv.se/Verktyg--stod/Statsliggaren/Regleringsbrev/?R $\mathrm{BID}=16532$

Swedish Government. (2014b). Regleringsbrev för budgetåret 2014 avseende Rikspolisstyrelsen och övriga myndigheter inom polisorganisationen (Appropriation Directions for the National Police Board and Other Authorities Within the Police Organization).
Retrieved 20 January 2015 from http://www.esv.se/Verktyg--stod/Statsliggaren/Regleringsbrev/?R $\mathrm{BID}=15843$

Swedish Migration Board. (2015). Aktuellt om ensamkommande barn och ungdomar (News on Unaccompanied Children and Adolescents) Retrieved 22 April 2015 from http://www.migrationsverket.se/download/18.39a9cd9514a346077 21343b/1425399445527/Aktuellt+om+ensamkommande+barn+oc $\mathrm{h}+$ ungdomar+mars+2015.pdf

UN Committee on the Rights of the Child. (2005). Treatment of Unaccompanied and Separated Children Outside their Country of Origin. Retrieved 20 January 2015 from http://www.refworld.org/docid/42dd174b4.html

UN General Assembly. (1948). Universal Declaration of Human Rights. Retrieved 20 January 2015 from http://www.refworld.org/docid/3ae6b3712c.html

UN General Assembly. (1989). Convention on the Rights of the Child. Retrieved 20 January 2015 from http://www.ohchr.org/Documents/ProfessionalInterest/crc.pdf

Westwood, J. L. (2012). Constructing Risk and Avoiding Need: Findings from Interviews with Social Workers and Police Officers Involved in Safeguarding Work with Migrant Children. Child Abuse Review, 21(5), 349-361

Zorn, J. (2009). The Right to Stay: Challenging the Policy of Detention and Deportation. European Journal of Social Work, 12(2), 247-260 